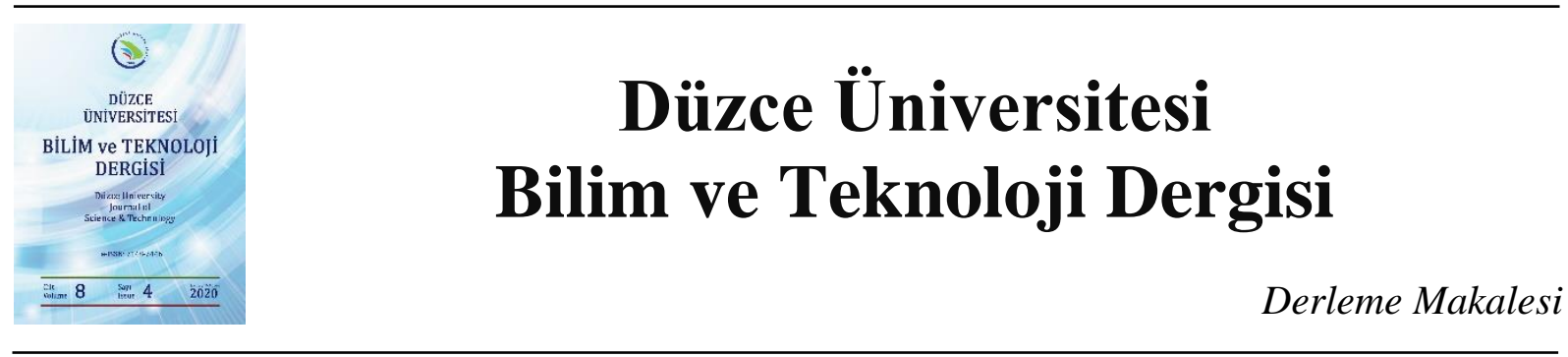

\section{Kozmetik Tekstillerin Üretimi, Karakterizasyonu ve Performans Testleri ile İlgili Bir Derleme}

\author{
Ejebay JUMAGELDIYEVA ${ }^{\text {a }}$, (D) Ayşe Ebru TAYYAR ${ }^{\text {b,* }}$, (D) Gamze D. TETIK ${ }^{\mathrm{c}}$ \\ ${ }^{a}$ Tekstil Mühendisliği Anabilim Dall, Fen Bilimler Enstitüsü, Uşak Üniversitesi, Uşak, TÜRKIYE \\ ${ }^{b}$ Tekstil Mühendisliği Bölümü, Uşak Üniversitesi, Uşak, TÜRKIYYE \\ ${ }^{c}$ Malzeme Bilimi ve Nanoteknoloji Mühendisliği Bölümü, Uşak Üniversitesi, Uşak, Türkiye \\ * Sorumlu yazarın e-posta adresi: ayseebru.tayyar@usak.edu.tr
}

DOI: $10.29130 /$ dubited.692129

\begin{abstract}
ÖZET
Geleneksel tekstiller; örtünme, korunma, destek ve süslenme gibi çeşitli işlevleri yerine getirmek amacıyla kullanılagelmiştir. Son zamanlarda, insanların doğal ve sağlıkl yollarla vücutlarına bakım sağlamaya yönelik artan eğilimleri ile sadece sıcaklık ve nem kontrolü gibi konfor özellikleri geliştirilmiş tekstil ürünleri değil, aynı zamanda hijyenik, koku salabilen, renk ve görünüm değiştirebilen, ileri düzey koruma gibi ekstra fonksiyonları da taşıyan giysi, ev tekstili ya da tekstil temelli bakım ürünleri de ön plana çıkmıştır. Tekstil mühendisleri, biyokimyagerler, eczacılar, kozmetik ve sağlık uzmanları yürüttükleri ortak çalışmalar ile her yeni gün kozmetik tekstiller alanına önemli katkılar sunmaktadırlar. Tekstil ürünlerine kozmetik işlevsellik kazandırmak için çeşitli metalik, bitkisel ve hayvansal içerikler saf ya da türev formunda kullanılmaktadır. Kozmetik tekstiller, kozmetik bir amaca hizmet eden aktif bir maddenin insan cildine temas esnasında transfer edilmesi için tasarlanmaktadır. Kozmetik ve/veya farmasötik bileşenler giysiyi oluşturan kumaşa aktarılarak, bileşen(ler)in vücudun doğal hareketiyle cilde uzun sürede transfer edilmesi sağlanmaktadır. Bu çalışmanın amacı, kozmetik tekstillerin fonksiyonellikleri, karakterizasyonları ve performans testleri ile ilgili mevcut literatürün genel bir özetinin ulusal literatüre kazandırılmasıdır.
\end{abstract}

Anahtar Kelimeler: Kozmetik Tekstiller, Fonksiyonel Tekstiller, Kozmetik, Cilt Bakımı

\section{A Review on Production, Characterization and Performance Tests of Cosmetic Textiles}

\begin{abstract}
Traditional textiles have been utilized for the purposes of covering, protection, support, and ornamentation. Recently, with the increasing tendency of people to care for their bodies in natural and healthy ways, it is not only textile products that have improved comfort properties such as temperature and humidity control, but also hygienic, odor-releasing, color and appearance changeable, advanced protective and functional clothing, home textiles or textile-based care products have stood out. Textile engineers, biochemists, pharmacists, cosmetics and health experts make important contributions to the field of cosmetics textiles with multidisciplinary studies. Various metallic, vegetable and animal originated ingredients are used in pure or derivative form to gain cosmetic functionality to textile products. Cosmetic textiles are designed to transfer an active agent serving for a cosmetic purpose during contact with human skin. The cosmetic and / or pharmaceutical components are transferred to the fabric forming the garment so that the component(s) can be transferred to the skin by the natural movement of the
\end{abstract}


body over a long period of time. The aim of this study is to provide a general summary of the existing literature on the functionalities, characterizations and performance tests of cosmetic textiles to the national literature.

Keywords: Cosmetic Textiles, Functional Textiles, Cosmetics, Skin Care

\section{GIRIS}

Cildin sağl1kl1, pürüzsüz, genç ve güzel görünmesi kişiler için önem arz ettiğinden, bu alanda kayda değer miktarlarda para ve zaman harcanabilmektedir. Kozmetik endüstrisi sürekli gelişmekte ve piyasaya her yeni gün nemlendiriciler, temizleyiciler ve güzellik ürünleri sürülmektedir. Ürünlerin büyük çoğunluğu aktif uygulama gerektirmektedir. Örneğin, yüz derisinin temizliği ve nemlendirilmesi için günlük bakım rutini önemlidir. Son yıllarda cilt bakımında kozmetik tekstiller adı altında yeni bir alanın gelişmeye başladığı gözlenmektedir. Kozmetik tekstillerin henüz emekleme aşamasında olduğu söylenebilir. Kozmetik tekstillerin en büyük avantajı kozmetik maddeyi aktif olarak uygulama gereksinimini ortadan kaldırmasıdır. Gece-gündüz kullandığımız tekstiller esas olarak bize koruma, sıcaklık ve destek vermek için tasarlanmıştır. Son yirmi yılda gelişen yeni teknolojiler, nefes alabilen tekstiller, akıllı tekstiller, tıbbı tekstiller ve daha yakın zamanlarda kozmetik tekstiller gibi özgün teknik tekstillerin gelişmesine yol açmıştır. Kozmetik tekstiller, tekstil malzemelerini kozmetik etken maddelerle birleştirme prensibine dayanmaktadır [1]. Yani, deri ile temas esnasında aktif bir maddenin kozmetik amaçlar için cilde transfer edilmesi için tasarlanmıştır. Piyasadaki mevcut kozmetik tekstiller, nemlendirici, selülit azaltıcı, koku yayan, vücut zayıflatma etkili, enerji verici, gençleştirici, canlandırıcı, cildin sıkılığını ve elastikiyetini arttıran veya ince çizgilerin ve kırışıklıkların görünümünü azaltmaya yardımcı olan ürünlerden oluşmaktadır [2].

Kozmetik aktif bileşenlerin tekstil ürünlerine aktarılması, kozmetik içerikli maddelerin fiziksel veya kimyasal olarak elyaf yüzeyine bağlanması ile gerçekleşmektedir. Kozmetik tekstiller, lif oluşturacak hammadde içerisine katkılama, lif, iplik ya da kumaş yüzeyine aşılayarak tutundurma, doğrudan kaplama ya da kapsülleme gibi çeşitli teknikler ile üretilmektedir [3].

Kozmetik tekstil alanındaki araştırmalar, ilk olarak Japonya'nın günümüzden 40 y1l önce tekstil bileşimine kozmetik kompozisyonu dâhil etmesiyle başlamıştır. 1995 yılında mikrokapsüllenmiş parfümlü atkılar, Avrupa'da ilk ticari mikrokapsüllenmiş tekstil ürünleri olarak Hermes tarafından piyasaya sürülmüştür. Kozmetik tekstillere yönelik uygulama yelpazesi, kozmetik ve tekstil endüstrisindeki yüksek profilli firmaların artan katılımıyla Aloe vera, zeytinyağı, C vitamini, E vitamini, kahve, koenzim Q10, maden suyu, kuşburnu yağı, tatlı badem yağ1, meyve ve bitki özütleri gibi doğal bileşenlerle mikrokapsüllenmiş ve hareket sırasında cilde farklı kozmetik etkiler sağlayan tekstil ürünleri geliştirilmişsir [4].

Kozmetik bileşenlerin tekstil ürünleri ile birleştirilmesi için pek çok firma, kozmetik tekstillerin doğduğu günden bugüne gerek lif yapısına kozmetik bileşenin dahil edilmesi, gerekse bitim işlemleri ile aktarılması yolu ile fonksiyonel ürün üretimine imza atarak piyasaya sürmüşlerdir. Bu ürünlerden bazıları Tablo 1'de verilmektedir.

Tablo 1. Ticari firmaların kozmetik tekstil ürünleri [3]- [6].

\begin{tabular}{|c|c|c|}
\hline $\begin{array}{l}\text { Ürün } \\
\text { türü }\end{array}$ & Ürünün sağladığı kozmetik etki & Ticari marka/firma \\
\hline Atk1 & Koku salma & Hermes \\
\hline Kumaş & Bacak ve ayaklara hassas bakım sağlama & Skintex $₫ /$ Cognis \\
\hline Kumaş & Vücut şekillendirme & $\begin{array}{l}\text { Lycra }{ }^{\circledR} \text { vücut bakım serisi/ } \\
\text { Invista firması Celessence }\end{array}$ \\
\hline Tayt & İnceltme ve selülit azaltma & Lytess \\
\hline Kot & Yasemin kokusu salma, selülit karşıtı ve nemlendirme & $\begin{array}{l}\text { Denim Spa Therapy for } \\
\text { Legs/ Wrangler }\end{array}$ \\
\hline
\end{tabular}


Tablo 1 (devam). Ticari firmaların kozmetik tekstil ürünleri [3]- [6].

\begin{tabular}{lll}
\hline Havlu & Kepek ve saç dökülmesine karşı etkili saç bakımı & Skin Up \\
\hline Yastık & Yaşlanma karışı, kırışıklık karsıtı & Beauty pillow \\
\hline Lif & $\begin{array}{l}\text {-Yumuşaklık, vücut nem dengesini koruma ve hücre yenileme } \\
\text {-Yumuşaklık ve hijyen sağlama }\end{array}$ & $\begin{array}{l}\text {-Tencel }{ }^{\circledR ~ C ~} \\
\text {-Sea CellTM / Lenzing }\end{array}$ \\
\hline \multirow{2}{*}{ Nanolif } & $\begin{array}{l}\text { Polimer matrisinde biyoaktif mineral kristalleri içererek vücut } \\
\text { 1sısını emme, kolajen sentezine yardımcı olma, cilt esnekliği ve } \\
\text { yumuşaklığını artırma, mikro dolaşım kan akışını artırma }\end{array}$ & Emana/ Solvay \\
\hline Lif & $\begin{array}{l}\text { Cildin elastikiyetini, yumuşaklığını geliştirme, sıkılaştırma, kolajen } \\
\text { üretimini arttırma }\end{array}$ & Meryl® Hyaluronan/ Nyistar \\
\hline Lif & $\begin{array}{l}\text { Yüksek direnç, vücutta sıvı yönetimi ve antibakteriyel koruma ve } \\
\text { vücut sıcaklığının dengesini sağlama }\end{array}$ & Nilit \\
\hline Lif & Cilt yenileme ve antibakteriyellik sağlama & SmartcelTM/AG Rudolstadt \\
\hline
\end{tabular}

Antibakteriyel ve iyileştirici olduğu bilinen kitosan polimeri de Crabyon` formunda viskona eklenmiştir. Hem Crabyon $(\mathcal{C}$ hem de selülit azaltıcı, inceltici, enerji verici ve sıkılaştırıcı etkileri ile diğer bazı kozmetik tekstil ürünleri, bazı araştırmalarda birer alternatif tıp ürünü olarak da ele alınmaktadır [7].

Tanınmış tekstil firmalarının kozmetik tekstillere karşı artan ilgisi, Türkiye'de de pek çok firmanın ArGe ve Ür-Ge birimlerinin, üniversite/enstitülerin çalışmalarında bu konuya odaklanmalarında etkili olmuştur. $\mathrm{Bu}$ derleme çalışmada kozmetik tekstillerin üretimleri, karakterizasyonu ve performans testleri detaylı şekilde anlatılmaktadır.

\section{KOZMETIK TEKSTILLERIN ÜRETIMI}

Kozmetik etki elde etmek için farklı üretim aşamalarında farklı teknikler kullanılarak tekstil malzemeleri üzerine çeşitli etken maddeler eklenmektedir. Şekil 1'de bu teknikler verilmektedir. Bu tekniklerin seçimi, kozmetik bileşenlerin ve tekstil malzemelerinin yapısına ve ilave edilecek kozmetik içerik miktarına göre değişmektedir [8], [9]. Vücudun doğal hareketi ile kumaşa aktarılan aktif bileşenler kontrollü olarak taşıyıcı sistemlerden insan cildine nüfuz etmektedir.

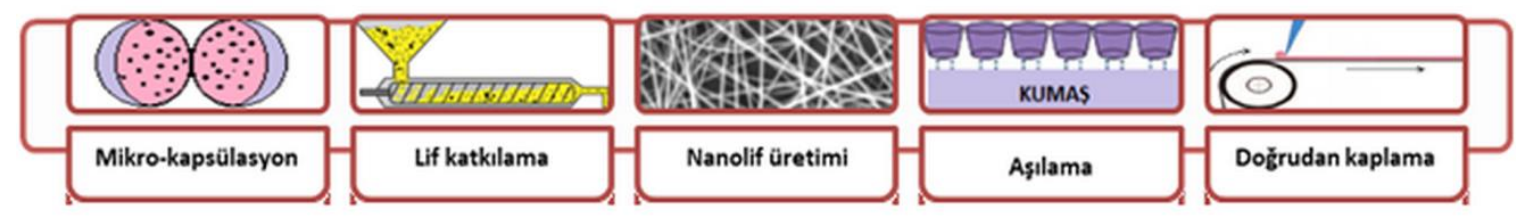

Şekil 1. Kozmetik tekstillerin üretim teknikleri

\section{A. MÍKROKAPSÜLASYON}

Kapsülleme, korunması istenilen bir malzeme ya da malzeme karışımının başka bir malzeme ya da sistem içinde hapsedildiği ya da tutulduğu tekniktir [10]. Kaplanmış malzemeye aktif ya da çekirdek malzeme denilmektedir. Kaplama malzemesi ise kabuk, duvar malzemesi, taşıyıcı ya da enkapsülan terimleri ile anılmaktadır [11]. Mikrokapsülleme, gaz, sıvı ya da katı bir malzemenin (çekirdeğin) etrafını çevreleyen ortamdan koruyan ve izole eden ve özelliklerini gerektiği gibi ayarlayan sağlam bir kabuk (kapsül) ile çevrelenip kaplandığı bir işlem olarak da tanımlanmaktadır. Başka bir deyişle, bir mikrokapsül, tipik olarak sentetik ya da doğal polimerler tarafından üretilen bir zarla çevrili aktif madde(ler) içeren bir haznedir [12].

Her alanda olduğu gibi tekstil sektöründe de fonksiyonel ürünlerin geliştirilmesi, öncelikli hale gelmiştir. Tekstil malzemelerine fonksiyonelliğin kazandırılması, lif üretimi aşamasında katkılama ile 
yapılabildiği gibi kumaşa uygulanan bitim işlemleri ile de sağlanabilmektedir [13]. Fonksiyonel tekstillerin üretiminde mikrokapsülasyon teknolojisi kapsüllenen maddenin etkisinin kullanıma kadar korunmasına olanak sağladığı için hem lif üretimi sırasında mikrokapsüllerin yaş lif çekim çözeltisine ilave edildiği çalışmalar [14] hem de çeşitli bitim işlemleri ile mikrokapsüllerin kumaşlara aktarıldığı çalışmalar mevcuttur [15].

Mikrokapsül çalışmaları, 1930'ların sonlarında kimyacı Baret Green ve arkadaşlarının, jelatin ile koaservasyon işlemini geliştirmesiyle başlamıştır. Ekip, çalışmalarının sonunda konu ile ilgili birkaç patent almıştır. Mikrokapsülleme ile ilgili çalışmalar, 1970'lere kadar popülarite kazanmamışken 1980'lerin ortalarında, gıda, kozmetik, tarım, bahçecilik, boya, baskı, fotoğrafçılık, bilgisayar, gübre, yapıştırıcılar, temizlik ve havacılık endüstrileri dahil olmak üzere çeşitli alanlardaki mikrokapsül çalışmaları hızla yayılmıştır [12].

Çapları $1 \mu \mathrm{m}$ 'den küçük kapsüller nanokapsüller, $1000 \mu \mathrm{m}$ 'den büyük kapsüller ise makrokapsüller olarak adlandırılmaktadır [16]. Ticari mikrokapsüllerin çapları genellikle 3-800 $\mu \mathrm{m}$ arasındadır ve \%1090 oranında çekirdek malzemesi içermektedir [17]. Mikrokapsülün kabuk kalınlığı 0,2 $\mu \mathrm{m}$ ile birkaç mikrometre arasında değişmektedir [12]. Şekil 2'de mikrokapsülün yapısı şematik olarak gösterilmektedir.

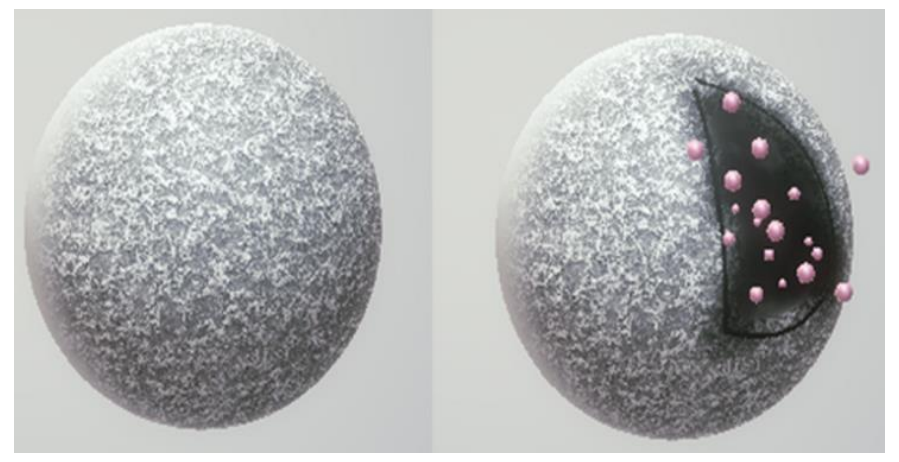

Şekil 2. Bir mikrokapsülün şematik gösterimi

Mikrokapsülasyonun amaçları, biyoaktif bileşeni (çekirdek) 1şıktan, atmosfer koşullarından, zararlı çevreden koruyabilmek, istenmeyen tat ve kokuları maskeleyebilmek ve raf ömrünü uzatabilmek olarak sayılabilir. Mikrokapsülasyon teknolojisi sayesinde toz ya da sıvı maddeler katı halde taşınabilmekte, kapsüllenmiş malzemenin hedefli ya da kontrollü salımı gerçekleştirilebilmektedir [17].

Mikrokapsüllerin en önemli özelliği, büyük bir yüzey alanına izin veren mikroskobik büyüklükleridir. Tamamen küresel formdaki çap1 $1 \mu \mathrm{m}$ olan bir mikrokapsülün yüzey alanı, çap $1 \mathrm{~mm}$ olan bir kapsülün yüzey alanından 106 kat daha büyüktür. Bu geniş yüzey alanı, adsorpsiyon ve desorpsiyonun gerektiği kimyasal reaksiyonların yer aldığı uygulamalar için önemlidir [16].

Mikrokapsül üretiminde kullanılacak olan yöntemin seçimi, kapsülü oluşturacak olan öz ve kabuk malzemelerinin türü, yapısı, kimyasal ve fiziksel özellikleri gibi pek çok parametreden etkilenmektedir [18]. Mikrokapsüllerin fonksiyonlarına göre sadece boyutları değil, aynı zamanda içerdikleri öz maddesini kontrollü bir şekilde salmaları da önemli bir husustur. Kozmetik ürünlerde de aktif maddenin kontrollü salımı büyük önem taşımaktadır. Yavaş ve sürekli salım mekanizması ile aşırı dozdan kaçınılarak kozmetik maddenin insan cildine kontrollü bir şekilde salınması söz konusu olmaktadır. Kontrollü salım, ilk defa 1950'lerin sonlarında ticari bir şirket tarafından ilaçları kapsüllemek ve kontrollü salımlarını sağlamak için uygulanmıştır. Aspirin, mide tahrişini önlemek için ilk mikrokapsül formunda üretilen ilaçlardan biridir. Kontrollü salımlı mikrokapsül teknolojisi uygulamalarına geç başlanmış olmasına rağmen, günümüzde farmasötikler alanında oldukça yaygın olarak kullanılmaktadır [19], [20]. C vitamini gibi maddeler ile cilt bakımına yönelik, aromaterapi, stres yönetimi etkili ya da biyomedikal amaçlı mikrokapsüllerin tekstil yüzeylerine aktarılmaları ile çeşitli kozmetik tekstiller 
üretilmiştir. Cilt bakımı etkili Aloe vera içeren mikrokapsüllü tekstil yüzeyleri de bu alana örnek olarak verilebilir [19].

\section{B. LIF KATKILAMA}

Lif katkılama başlı̆̆ 1 altındaki çalışmalar daha çok nanolifli, elektrolif çekim yöntemi ile üretilen tekstilleri kapsamaktadır. Kozmetik amaçlarla üretilen nanolifler ayrı bir başlık altında ele alındığından burada sınırlı sayıdaki mikrolif katkılama çalışmasına değinilmiştir. Mikrolifler, genellikle 0,1-1,2 dtex aralığında poliester, poliamid, akrilik gibi sentetik lifler ve modal, lyocell ve viskoz gibi rejenere liflerden üretilmektedir. Mikrolifler kullanım amacına bağlı olarak kesikli stapel veya kesiksiz filament şeklinde üretilmektedir [21]. Mikrolifler, konvansiyonel lifler ile karşılaştırıldıklarında kumaşlara lüks görünüm, iyileştirilmiş fiziksel ve tutum özellikleri ve yüksek seviyede giyim konforu sağlamaktadır. Mikrolifler ile üretilen tekstil ürünleri geleneksel tekstillerin yanı sıra, fonksiyonel teknik tekstillerin üretiminde de yaygın olarak kullanılmaktadır [22], [23]. Kozmetik alanında; antienflamatuvar, iyileştirici ve renk verici özellikleri olan zencefil ile katkılanmış polilaktik asit lifleri eriyikten çekim yöntemi ile üretilmiş ve termal, yapısal ve mekanik özellikleri araştırılmıştır [24]. Ayrıca Bombyx mori ipeğinin üç farklı katkılama ajanı ile katkılanması ile liflerin üretilip, mekanik, termal ve elektriksel özelliklerinin incelendiği, kozmetik alanında da uygulanma potansiyeline sahip akıllı tekstillerin üretimini içeren bir çalışma da Rudilosso tarafından sunulmuştur [25].

\section{NANOLIFLER}

Cüce anlamına gelen "nano" fiziksel ölçü birimlerinde önek olarak kullanıldığında ilgili ölçüm biriminin milyarda birini tanımlamaktadır, yani herhangi bir fiziksel büyüklügü̈n milyarda birine nano denilmektedir. Ticari ürünlerde yaygın olarak kullanılan nano parçacıklar 1-100 nm arasındadır [26]. Nano kavramı ilk defa 1959 yılında bir fizikçi olan Richard Feynman tarafından ortaya atılmıştır. Nanoteknoloji önceleri hak ettiği ilgiyi göremese de 1990'larda başlayan akademik ilgi ile bilim camiasının en sıcak gündem maddelerinden biri haline gelmeyi başarmıştır ve halen güncelliğini korumaktadır. Popülaritesinin altında pek çok uygulama alanına yönelik malzemenin kusursuz bir şekilde üretimine izin vermesi yatmaktadır. Tekstil endüstrisi de günümüzde nanoteknolojinin nimetlerinden çokça yararlanan sektörlerden biri durumundadır [27]. Nanoteknoloji sayesinde farklı fonksiyonlara sahip nano boyutlarda yapı malzemelerinden oluşan yeni tekstil ürünleri nanolifler ya da nanokompozitler üretilebilmektedir [6]. Tekstil malzemesinin mevcut fonksiyonlarını; lif, iplik veya kumaş yüzeyine farklı özellikler kazandıran nanopartiküller ekleyerek geliştirmek de mümkündür.

Nanoteknoloji kullanarak tekstillere kazandırılan özellikler arasında su geçirmezlik, kırışmazlık, antibakteriyellik, anti-statiklik, UV koruma, alev geciktiricilik, geliştirilmiş boyanabilirlik, kolay temizlenebilirlik, su ve leke tutmazlık ve koku önleyicilik gibi özellikler sayılabilmektedir [28]. Bunların tümü bir boyutlu nanomalzemeler sınıfına giren nanolifler ile gerçekleştirilemese de nanoliflerin tekstil kumaşlarının çeşitli performanslarını arttırdığı çalışmalar mevcuttur. Burada sadece kozmetik alanında yapılan çalışmalara değinilmiştir. Yılmaz vd. (2016)'nin de sınıflandırdığı gibi nanolifli kozmetik yapılar yüz maskeleri ve cilt temizleyiciler, cilt sağlığı arttırıcı ve yenileyici ürünler, cilt yaraları iyileştirici ürünler olmak üzere üç temel kategoride toplanmaktadır [29]. Nanoliflerin sahip olduğu yüksek yüzey alanı, düşük çap, yüksek dayanım, yüksek gözeneklilik ve düşük gözenek boyutu, hafiflik gibi eşsiz özellikler [6], her üç alanda da avantaj sağlamaktadır.

A ve E vitaminlerinin elektrolif çekim çözeltisine ilave edilerek selüloz asetat nanolifli tekstil yüzeylerinin oluşturulduğu araştırmada salım profilleri belirlenmiştir [30]. G. mangostana özütünün kitosan nanoliflerine yüklendiği bir diğer çalışmada antimikrobiyal ve antioksidan kozmetik amaçlı tekstil yüzeyleri üretilmiş ve karakterize edilmiştir [31].

Tekstil yüzeylerinin üzerine sıfır boyutlu (0D) nanomalzeme aktarımı ile gerçekleştirilen bitim işlemleri yaygın olsa da literatürde nanoliflerin doğrudan kozmetik amaçlarla kullanıldığı araştırmaların sınırlı sayıda olduğu görülmektedir. 


\section{AŞILAMA}

Kozmetik tekstil ürünlerinin üretiminde kullanılan bir diğer yöntem de aşılamadır. Aş1lama siklodekstrinler ile yapılabilmektedir. Siklodekstrinler, supramoleküler kimyada ev sahibi molekül olarak tanımlanmaktadır (Şekil 3). Farklı özelliklere sahip iki veya daha fazla molekül, iyon ya da koordinasyon bileşiklerinin molekül içi etkileşimler ile birleşmesi sonucu oluşan kompleksler, supramoleküller olarak adlandırılmaktadır. Bu etkileşimlerin çoğu ev sahibi ve misafir tipinde olmaktadır. Supramoleküler kimyada ev sahibi moleküller, kriptandlar, taş eterler, kalikserenler, siklotanlar ve siklodekstrinler gibi kafes yapısında olan bileşiklerdir [32].

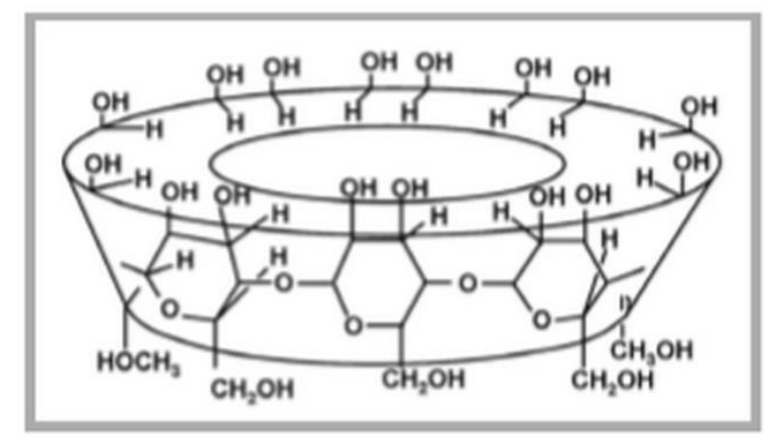

Şekil 3. Siklodekstrinin molekül yapısı [3]

Siklodekstrinler, nişastanın transglikozilaz enzimi ile enzimatik parçalanması sonucu endüstriyel olarak üretilmektedir. Siklodekstrinler, homojen ve kristal yapıda olmakla birlikte higroskopik değillerdir. Siklodekstrinler en az altı tane glikoz halkasına sahiptir ve daha küçük siklodekstrinler sterik etkilerden dolayı oluşamamaktadır. Ticari olarak üretilen siklodekstrinler, 6 ( $\alpha$-siklodekstrin), 7 ( $\beta$-siklodekstrin) ve 8 ( $\gamma$-siklodekstrin) glikoz halkasına sahiptirler. Moleküldeki glikoz halkalarının sayısına bağlı olarak siklodekstrinler farklı içyapılara sahiptirler. Siklodekstrinler, halka şeklinde olup bu yapı üstten kesik koniye benzemektedir. Siklodekstrinler, polar hidrofilik dış yüzeye ve hidrofobik iç yüzeye sahip olmalarından dolayı hidrofilik ortamda hidrofob bileșenlere ev sahipliği yapabilmektedir [33], [17].

Siklodekstrinler kristal haldeyken, iki tip kanal ve kafes formunda bulunmaktadır. Kanal formundayken, kafa-kuyruk ya da kafa-kafa formunda birbirleri üzerine dizilip, iç boşlukları kanal oluşturmakta ve misafir moleküller bu kanal içerisine dizilmektedir [17]. Siklodekstrinler kafes formundayken, iç kısımlarındaki boşluk sayesinde başka moleküller bu boşluğa girerek inklüzyon kompleksi oluşturmakta ve misafir moleküller siklodekstrin boşluğu tarafından tutulmaktadır. Bu kompleks sayesinde misafir moleküllerin oksidasyon, hidroliz, fotokimyasal reaksiyonlara karşı dayanımının artması, uçucu maddelerin buharlaşma hızlarının önemli ölçüde azalması ve bunların daha düzenli ve kontrollü olarak serbest bırakılması sağlanabilmektedir. Sahip oldukları bu özelliklerden dolayı siklodekstrinler eczacılık, kozmetik, gıda, çevre koruma, tekstil vb. pek çok alanda değişik amaçlarla kullanılmaktadır [34].

\section{E. DOĞRUDAN KAPLAMA}

Örme, dokuma ya da dokusuz yüzey olarak üretilen kumaşın bir ya da her iki yüzeyini kimyasal bir madde ile kaplayarak kaplama kumaşlar elde edilmektedir. Ayrıca iplik formunda da kaplama uygulanabilmektedir. Tekstil kaplama proseslerinde genellikle dokuma kumaşlar tercih edilmektedir. Kaplama, kumaşa normal terbiye prosesleriyle kazandırılamayan özel efektler için uygulanan bir işlemdir. İstenilen efekte göre sıvı, hamur veya toz halde bulunan kimyasallar toz, pasta veya köpük formunda kumaşa aktarılarak kumaş üzerinde bir film tabakası oluşturulmaktadır [35].

Estetik ve dekoratif özelliklerin yanında tekstil ürünlerinin teknik veya fonksiyonel özelliklerinin artırılmasına yönelik üretilen koruyucu ve spor tekstillerinde özellikle yüksek performans, sağlamlık, konfor gibi parametrelerin önemli olduğu yerlerde modern kaplama teknolojileri kullanılmaktadır [36]. 
Kaplama maddelerinin hepsi uzun zincirli lineer moleküller olan termoplastik polimerlerdir. Son ürünün dayanıklılığını ve performansını, doğrudan bu maddelerin özellikleri etkilemektedir [37].

Klasik kaplama tekniklerinin yanı sıra son yıllarda kullanımı giderek artan plazma ve sol-jel teknolojileri gibi modern teknikler de bulunmaktadır [38].

\section{KOZMETIK TEKSTILLERIN SINIFLANDIRILMASI}

Literatürde kozmetik tekstillerin genel kabul gören bir sınıflandırması mevcut olmasa da araştırmacılar kozmetik tekstilleri çeşitli şekillerde sınıflandırmaya çalışmışlardır. Genellikle insan vücudu üzerinde yarattıkları etkiye göre bir sınıflandırma ile karşılaşıldığından burada da bu sınıflandırma tercih edilmiştir.

\section{A. NEMLENDİRME ETKİLI KOZMETIKK TEKSTÍLLER}

Nemlendirme etkisi olan nanopartiküller, Aloe vera özü, skualen, ipek, seramid, kolajen peptit gibi maddelerden yapılmaktadır. Bilindiği gibi Aloe vera özü, sakinleştirici, nemlendirici, antioksidan ve cilt koruyucu özelliğe sahiptir. İpek proteininin en önemli özelliği ise nemlendirici ve cildi yumuşatıcı özelliğe sahip olmasıdır [3].

Kolajen ve peptit gibi maddeler, cildi nemlendirmekte ve cildin yaşlanmasına sebep olan etkenlere karş1 savaşmaktadır. Genelde cilt bakımı ve nem kontrolünde kullanılan seramid cildin yüzeyini yeniden şekillendirerek ipeksi ve yumuşak hale getirmekte, cildi daha genç ve pürüzsüz göstermektedir [39].

Nanoteknoloji sayesinde hidrofil karakterde olan kozmetik tekstil yüzeylerinin geliştirilmesi sağlanabilmektedir ve fotokatalitik etkili $\mathrm{TiO}_{2}$ 'nin entegrasyonu ile tekstil yüzeylerinde nem emilim olasılı̆̆ 1 arttırılabilmektedir [40]. Günlük nemlendirici dozunun vücuda aktarılması için klasik bir külotlu çorapta \%4 oranında nemlendirici bulunabilmektedir [28], [41].

\section{B. KOKU YAYAN KOZMETIK TEKSTILLER}

Mikrokapsüller içine gizlenmiş özel üretilmiş parfüm esansları yürüme esnasında oluşan 1sı veya sürtünme enerjisi sayesinde etrafa salınmaktadır. Parfüm esansları içeren mikrokapsüller ile hazırlanmış kumaşlardan oluşan takım elbiseler, her daim güzel kokmanın yanı sıra çevreden gelen diğer kokuların baskılanması açısından avantajlıdır. Tekstil ürünlerine koku yayma işlevselliğini eklemek için çeşitli sentetik ve doğal ürünler kullanılmaktadır. Kitin, kitosan, asetil-glukozamin, D-glukosamid doğal polimerleri ve karanfil, yasemin, lavanta, çördük, sandal ağacı, gül ve buhur gibi çeşitli uçucu yağlar, parfüm etkisinin elde edilmesinde kullanılmaktadır. Koku yayacak olan uçucu bileşenin bir tekstil malzemesine ilavesi, lif çekimi sırasında ya da bitim işlemi aşamasında gerçekleştirilebilmektedir [42]. 2006 yılında Celessence, 2007 y1lında ise Devan Chemicals firması tarafından aromaterapi yağları içeren ve koku yayma özelliğine sahip tekstil ürünleri geliştirilmiştir [43].

\section{RAHATLATICI KOZMETIK TEKSTILLER}

Giysilerden algilanan serinlik hissi, hem mikrokapsül formunda faz değiştiren malzemeler ile hem de yüksek nem geçirgenliği olan yüzeyler ile insan vücudu arasındaki temas alanını arttırarak sağlanabilmektedir. Terlemeye en çok eğilimli olan koltukalt1, sırt, göğüs ve omuzlar gibi vücut bölgelerine yüksek soğutma ya da ferahlatma gereklidir. Skintex ${ }^{\circledR}$ şirketi 2004 yılında Supercool adını verdiği vücut temas alanını arttıran dikişsiz çok ince poliamid/elastan ipliklerden oluşan yeni bir ürününü piyasaya sunmuştur. Kontrollü salım yapan mikrokapsül mekanizması ile geliştirilen Supercool 
giysileri, vücut 1sısı ve sürtünme meydana geldikçe içerdiği doğal aktif bileşenler (cilt yumuşatıcı, mentol, myritol, sentetik soğutucu) sayesinde vücuda serinlik ve ferahlık etkisi sağlamaktadır [44], [3].

\section{CANLANDIRICI ETKILİ KOZMETIK TEKSTILLER}

Zencefil, mentol, portakal veya biberiye gibi bitki ve meyve bazlı bileşenlerin sentezlediği aromalar sayesinde canlandırıcı etki sağlayan kozmetik tekstiller geliştirilmektedir. $\mathrm{Bu}$ bileşenler mikrokapsülasyon tekniği ile tekstil yüzeylerine aktarılabilmektedir. Birkaç yıkamadan sonra bu işlev dayanıklılığını kaybetmektedir. Canlandırıcı kozmetik ürünler, bornoz ve havlu gibi ürünlere uygulanabilmektedir [3].

\section{E. ULTRAVIYOLE (UV) KORUMA ÖZELLİKLİ KOZMETİK TEKSTILLER}

Uzun süre UV ışınlarına maruz kalmak, güneş lekeleri, erken cilt yaşlanması, alerjiler ve hatta cilt kanseri gibi cilt hasarları ile sonuçlanabilmektedir. Bu hasarlara karşı etkili koruma sağlayabilen tekstiller, UV koruması için kozmetik tekstiller olarak adlandırılır. UV radyasyonuna karşı cildin korunmas1, direk olarak kumaş örtme faktörü tarafından belirlenmekle birlikte örgü tipi, kumaş alan yoğunluğu, esneklik, nem ve kumaşın yıkama döngüsünden de etkilenmektedir. 1,2-etandiol, çinko nanopartiküller, demir oksit, çinko oksit, titanyum oksit, karbon siyahı, bi-reaktif oksalik asit, dianitid türevleri ve çeşitli diğer kimyasallar, tekstil ürünlerinin UV koruma faktörünü (UPF) iyileştirmek için kullanılmaktadır [46].

\section{F. DİĞER KOZMETÍK TEKSTİLLER}

Cilt sıkılığını ve elastikiyetini arttırmaya yardımcı olan, zayıflatıcı etkili ve enerji veren kozmetik tekstiller bu grup altında toplanabilir. Cildi sıkılaştırma özelliğine sahip bazı doğal maddelerin tekstil ürünlerine aplikasyonu ve bu tekstil ürünlerinin kullanımı ile cildin sık1lığı ve elastikiyeti kontrollü bir şekilde geliştirilebilmektedir. Padina Pavonica bitkisinin cildin sıkılığını ve elastikiyetini arttırdığı bilinmektedir. Padina Pavonica, Akdeniz'de bulunan kahverengi alglerin koruyucu kaplamalarından elde edilir. Cildin sıkılığını ve elastikiyetini arttırmaya yardımcı olan, ticari ismiyle Hydrabra olarak adlandırılan iç çamaşırları piyasaya sürülmüştür. Hydrabra, Pavonica özleri ve nemlendirici losyon emdirilmiş ultra ince kumaştan özel olarak tasarlanmıştır [3]. Legends \& Heroes tarafından Ript Skinz markası altında karite yağı, kayısı çekirdeği yağı, kuşburnu yağı, kırmızı alg özü, kafein, retinol ve E vitamini gibi doğal bileşenler ile mikrokapsüllenerek hazırlanan giysiler piyasaya sürülmüsstür. $\mathrm{Bu}$ giysiler cildi gençleştiren, sıkılaştıran ve nemlendiren patentli kozmetik cilt bakım formülü ile ortalama 10 yıkamaya kadar dayanabilmektedir. Bu dayanım malzemenin sprey sayesinde kumaşa yeniden aktarımı ile uzatılabilmektedir [4].

Son yıllarda, zayıflatma etkisine sahip kozmetik tekstillerin dünyada hem kadınlar hem de erkekler için cazip ürünler haline geldiği söylenebilir. İplik özellikleri, kumaş yapısı ve bitim işlemlerine göre zayıflama etkisi oluşturmaya çalışan tekstil yapıları zayıflama etkili kozmetik tekstiller olarak adlandırılmaktadır. Cerrahi müdahale ve yoğun egzersiz gibi pahalı ve zor yollardan başka, selülitleri azaltmanın diğer bir yolu olarak ortaya çıkan kompresyonlu giysiler zayıflama için özel bir seçenek sunmaktadır. Ayrıca kompresyonlu giysiler kas hasarında azalma ve kas işlevini sürdürme konusunda da bir avantaj sağlamaktadır. Bu giysiler, damarlardaki kan akışını hızlandırarak ve oradaki dokunun daha çok oksijen tüketmesini ve canlanmasını sağlayarak daha güzel bir görünüş etkisi sağlamaktadır. Zayıflama için kullanılan kozmetik tekstiller, kullanıcılara zayıflamanın yanında rehabilitasyon etkisi de sağlamaktadır [47]-[48]. Zayıflatma etkisi olan kumaşlara uygulanan maddeler 1sı yayma etkisi ile yağ yakıcı ve zayıflatıcı özelliklerdedir. Bu maddeler cilt tarafindan kolaylıkla emilir ve cildi nemlendirir, ferahlık hissi verir, vücuttaki oksijeni arttırarak vücudun savunma sistemini güçlendirir. Ayrıca hücre yenilenmesine katkıda bulunarak bağışıklık sisteminin güçlenmesine ve vücuttaki toksinlerin atılmasina yardımcı olur [39]. 
Türkiye'de İpekiş firmas 2008 yılında, nano enerjiyle vücuttaki yağları yakabilen kumaş üretmiştir. Şili acı biberi, ahududu, zeytinyağı gibi bazı gıda ürünlerinin özütlerini nanoteknolojiden faydalanarak kumaşa aktarmıştır. Kumaş vücudun hareketi ile birlikte oluşan 1sı enerjisi vücuttaki yağların yakılmasına yardımcı olmaktadır [42].

Bir insanın enerji seviyesini yükseltmeye yardımcı olan tekstil ürünleri enerji veren kozmetik tekstiller olarak adlandırılmaktadır. İnsan vücudu hücreleri, hareket ve enerji seviyesini arttırmak için doğal bir antioksidan olan Q10 koenzimi kullanır [3]. Kozmetik tekstillerin kullanımı ile kremlere gerek kalmadan istenilen etken madde istenilen miktarda insan cildine aktarllır. Enerji veren etken maddelerle dolu mikrokapsüller kumaşa yerleştirilir ve zaman içinde yavaş yavaş cilde salınır. Ticari ismi Freeskin olan giysilerde, cilt bakım özellikleri taşıyan kitin polimeri ile üretilen mikrokapsüllerin içine bitkilerden elde edilen uçucu yağlar yerleştirilmektedir. Bu giysilerin giyildiği sürece cildin bakım görmesinin ve vücuda enerji vermesinin yanı sıra sinek kovucu özelliği de bulunmaktadır [42].

\section{KOZMETIK ÜRÜNLERDE YAYGIN OLARAK KULLANILAN MADDELER}

Genel olarak, kozmetik bileşenler inorganik ve sentetik kimyasallar, hayvansal ve bitkisel esaslı etken maddelerden oluşmaktadır. Demir oksit, çinko nanopartikülleri, titanyum oksit, çinko oksit sentetik ve organik bileşikleri olarak en sık kullanılan içeriklerdir [49]. İnsanlar, kozmetik olarak inorganik, sentetik kimyasallar ve hayvansal içeriklerden kaçınmaktadırlar. Çeşitli bilimsel ve tıbbi araştırmalar, bitkisel içeriklerin kozmetik ve kimyasal olarak hayvansal içeriklerden daha güvenli olduğunu göstermektedir [44]. Tablo 2'de kozmetik alanında yaygın olarak kullanılan maddeler ve içeriklerin elde edildiği kaynaklar ve fonksiyonları listelenmiştir.

Tablo 2. Bitkisel, Hayvansal Kaynakl, İnorganik ve Sentetik Kozmetik Maddeler

\begin{tabular}{|c|c|c|c|c|c|}
\hline Tür & Madde Adı & Etkisi & $\begin{array}{l}\text { Kullanıldığı kozmetik } \\
\text { ürün }\end{array}$ & Karakterizasyon testleri & Kaynak \\
\hline \multirow{3}{*}{ 胥 } & Aloe Vera & $\begin{array}{l}\text { - Bakteri karşıtı } \\
\text { - Virüs karşıtı } \\
\text { - Mikotik karşıtı } \\
\text { - Akne Vulgaris } \\
\text { - Yara iyileştirici } \\
\text { - İltihaplanma } \\
\text { karşıtı } \\
\text { - Yaşlanma karşıtı } \\
\text { - Cilt lekesi azaltıcı }\end{array}$ & $\begin{array}{l}\text { - Jel kapsül (Kırışıklık } \\
\text { ve yaşlanmaya karşı } \\
\text { etki) } \\
\text { - Aloe vera yaprak } \\
\text { ekstreleri } \\
\text { (Cilt lekesi azaltıcı etki) } \\
\text { - \%50 Aloe vera jeli \% } \\
\text { 0.5' lik tretinoin kremle } \\
\text { kombin (akne vulgaris } \\
\text { üzerindeki etkisi) }\end{array}$ & $\begin{array}{l}\text { - Visiometre SV } 600 \text { ile } \\
\text { kırışıklı ölçümü } \\
\text { - Cutometer MPA } 580 \text { ile cilt } \\
\text { elastikiyet ölçümü } \\
\text { - Kantitatif eş zamanlı RT-PCR } \\
\text { - HPTLC } \\
\text { - MMSI (melanofor boyut } \\
\text { indeksi) }\end{array}$ & $\begin{array}{c}{[4]} \\
{[50]-[53]}\end{array}$ \\
\hline & Ginseng & $\begin{array}{l}\text { - Kansere karşı } \\
\text { koruma } \\
\text { - İltihaplanma } \\
\text { karşıtı } \\
\text { - Bağ1ş1klık } \\
\text { sistemini } \\
\text { kuvvetlendirici } \\
\text { etkisi } \\
\text { - Fiziksel } \\
\text { performans } \\
\text { arttırıcı etkisi }\end{array}$ & $\begin{array}{l}\text { - Ginseng özütü (Alerji } \\
\text { karşıtı etki, hafıza } \\
\text { güçlendirici etki) }\end{array}$ & $\begin{array}{l}\text { - IC50 (\% } 50 \text { engelleyici } \\
\text { konsantrasyon) } \\
\text { - EC50 (\%50 etkili } \\
\text { konsantrasyon) } \\
\text { - Kavramsal ve hafiza } \\
\text { performansı } \\
\text { - Oral ilaç uygulama } \\
\text { - Gönüllü insan denekleri } \\
\text { - Bilişsel ve duygu durum } \\
\text { testleri }\end{array}$ & {$[54]-[58]$} \\
\hline & Meyveler & $\begin{array}{l}\text { - Dinçleştirme } \\
\text { - Rahatlama } \\
\text { - Antioksidan }\end{array}$ & $\begin{array}{ll}\text { - Cucumis } & \text { sativus } \\
\text { meyvesinin } & \text { (CSLJ) } \\
\text { liyofilize suyu } & \end{array}$ & $\begin{array}{l}\text { - Antioksidan, anti- } \\
\text { hiyalüronidaz ve anti-elastaz } \\
\text { aktiviteleri } \\
\text { - DPPH antioksidan testi } \\
\text { - HPLC } \\
\text { - IC } 50\end{array}$ & {$[59]-[60]$} \\
\hline
\end{tabular}


Tablo 2 (devam). Bitkisel, Hayvansal Kaynakl, İnorganik ve Sentetik Kozmetik Maddeler

\begin{tabular}{|c|c|c|c|c|c|}
\hline \multirow{5}{*}{ 践 } & $\begin{array}{l}\text { Uçucu } \\
\text { yağlar }\end{array}$ & $\begin{array}{l}\cdot \text { Nemlendirme } \\
\cdot \text { Ferahlatma } \\
\cdot \text { Sağlıklı yaşam } \\
\quad \text { etkileri }\end{array}$ & $\begin{array}{l}\text { - Narenciye yağı ve E } \\
\text { vitamini kombinasyonu } \\
\text { (bakteri ve mantar karşıtı } \\
\text { etkiler) }\end{array}$ & $\begin{array}{l}\text { - Mikrobiyolojik testler } \\
\text { - Emülsiyon stabilitesi testi }\end{array}$ & [61]-[63] \\
\hline & Çiçekler & $\begin{array}{l}\cdot \text { Nemlendirme } \\
\cdot \text { Ferahlatma } \\
\cdot \text { Cilt aydinlatma } \\
\end{array}$ & $\begin{array}{l}\text { - P.persica çiçek } \\
\text { ekstraktı (cilt aydınlatıcı } \\
\text { etki) }\end{array}$ & $\begin{array}{l}\text { - DPPH testi } \\
\text { - Anti-tirozinaz aktivite testi } \\
\text { - IC50 }\end{array}$ & $\begin{array}{c}{[59],[3],} \\
{[64]}\end{array}$ \\
\hline & $\begin{array}{l}\text { Padina } \\
\text { Povanica }\end{array}$ & $\begin{array}{l}\text { - Cildin sıkılı̆̆ } 1 \\
\text { arttırma } \\
\cdot \text { Elastikiyet } \\
\text { arttırma } \\
\text { - Kanser önleyici } \\
\text { - Bakteri karşıtı }\end{array}$ & $\begin{array}{l}\text { - Bitki ekstraktı (kanser } \\
\text { önleyici etki) }\end{array}$ & $\begin{array}{l}\text { - DPPH antioksidan testi } \\
\text { - Antifungal aktivite testi } \\
\text {-Folin-Ciocalteu reaktifi ile } \\
\text { toplam fenol içeriği testi } \\
\text { - IC } \text { IC } \\
\text { - Sitotoksisite testi } \\
\text { - MTT (hücre canlılığı testi) } \\
\text { - DNA parçalanması } \\
\text { - Ak1ş sitometrisi }\end{array}$ & [65]-[68] \\
\hline & Hinokitiol & $\begin{array}{l}\text { - Bakteri, küf ve } \\
\text { böceklerin } \\
\text { önleme } \\
\text { · Bakteri karşitı } \\
\text { · Rahatlama }\end{array}$ & $\begin{array}{lr}\text { - Hinokitiolün } & \text { seri } \\
\text { dilüsyonları } & \text { (Chlamydia } \\
\text { trachomatis } & \text { bakterisi } \\
\text { üzerindeki bakteri karşı1t } \\
\text { etki) }\end{array}$ & $\begin{array}{l}\text { - In vitro deneyleri } \\
\text { - MIC (antimikrobiyal duyarlılık } \\
\text { testi) } \\
\text { - MLC (minimum ölümcül } \\
\text { konsantrasyon) } \\
\text { - MCC (preinokülasyon minimal } \\
\text { mikrobisidal konsantrasyon } \\
\text { deneyleri) }\end{array}$ & {$[69]-[71]$} \\
\hline & E vitamini & $\begin{array}{l}\cdot \text { Oksidasyon } \\
\text { önleyici } \\
\cdot \text { Nemlendirme } \\
\end{array}$ & $\begin{array}{l}\text { - E vitamini içeren çok } \\
\text { fonksiyonlu formülasyon } \\
\text { (yaşlanma karşıtı etki) }\end{array}$ & $\begin{array}{l}\text { - } 90 \text { günlük insan deneyleri } \\
\text { (direk temas) }\end{array}$ & $\begin{array}{c}\text { [72], [4], } \\
{[73]}\end{array}$ \\
\hline \multirow{3}{*}{ 焉 } & Skualen & $\begin{array}{l}\cdot \text { Yaşlanma önleme } \\
\cdot \text { Doğal yenileme } \\
\text { sağlama } \\
\cdot \text { Nemlendirme } \\
\cdot \text { Tümör önleyici } \\
\end{array}$ & $\begin{array}{l}\text { - Foto-oksitlenmiş saf } \\
\text { skualen (UV kaynaklı cilt } \\
\text { hasarına karş1 etki) }\end{array}$ & $\begin{array}{l}\text { - GC-MS } \\
\text { - In vivo deneyleri }\end{array}$ & {$[74]-[76]$} \\
\hline & Kitosan & $\begin{array}{l}\text { - Yara iyileştirme } \\
\text { - Bakteri karşıtı } \\
\text { - Pıhtılaşma } \\
\text { sağlayıcı }\end{array}$ & $\begin{array}{l}\text { - Kitosan çözeltisi } \\
\text { (mikrop ve tümör karşı1t1 } \\
\text { etkiler) }\end{array}$ & $\begin{array}{l}\text { - MTT } \\
\text { - In vitro deneyleri } \\
\text { - İstatistiksel analiz }\end{array}$ & {$[77]-[78]$} \\
\hline & Serisin & $\begin{array}{l}\text { - Nemlendirme } \\
\text { - Yaşlanma karşıtı } \\
\text { - Kırışılık önleyici }\end{array}$ & $\begin{array}{l}\text { - İpek serisin ekstraktı } \\
\text { (yaşlanma karşı1tı etki) }\end{array}$ & $\begin{array}{l}\text { - MTT } \\
\text { - In vitro deneyleri } \\
\text { - İstatistiksel analiz }\end{array}$ & [79]-[81] \\
\hline \multirow[t]{2}{*}{ 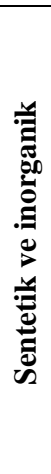 } & $\begin{array}{l}\text { Demir oksit, } \\
\text { Titanyum } \\
\text { oksit, Çinko } \\
\text { oksit, çinko } \\
\text { partikülleri, } \\
\text { bi-reaktif } \\
\text { oksalik asit, } \\
\text { 1-2 etandiol, } \\
\text { karbon } \\
\text { siyahı, dinatit }\end{array}$ & $\begin{array}{l} \\
\text { · UV } \\
\text { Radyasyonuna karş1 } \\
\text { koruma }\end{array}$ & $\begin{array}{ll}\quad \mathrm{ZnO} \text { ve } & \mathrm{TiO}_{2} \\
\text { nanoparçacıklı } & \\
\text { formülasyonlar } & (\mathrm{UV} \\
\text { koruma ve bakteri } & \text { karşı1t1 } \\
\text { etki) } & \end{array}$ & $\begin{array}{l}- \text { SEM } \\
\text { - EDX }\end{array}$ & $\begin{array}{c}{[82],[3],} \\
{[83]}\end{array}$ \\
\hline & Bakır oksit & $\begin{array}{l}\cdot \text { Yara iyileştirici } \\
\cdot \text { Mikrop karşıt1 }\end{array}$ & $\begin{array}{lrr}- & \text { Bakır } & \text { oksit } \\
\text { nanoparçacıkları } & \text { (mikrop } \\
\text { karşıtı etki) } & \end{array}$ & $\begin{array}{l}\text {-XRD } \\
\text { - MIC } \\
\text { - İstatistiksel analiz }\end{array}$ & [84]-[86] \\
\hline
\end{tabular}

\section{KOZMETIK TEKSTILLERIN STANDART TESTLERI VE KARAKTERIZASYONU}

Kozmetik tekstillerle ilgili yapılan literatür araştırmaları sonucunda bu alanda ciddi bir eksiklik olduğu göze çarpmaktadır. Kozmetik tekstiller vücudu sarmakta ve ten ile bire bir temas halinde bulunmaktadır. 
$\mathrm{Bu}$ nedenle, bu giysilerin kozmetik etkinliklerinin cilt üzerinde yaratacağ1 etkilerinin tespiti de insan sağlığı açısından büyük önem taşımaktadır [49].

Kozmetik madde dağıtım sisteminin biyouyumluluğu, kozmetik tekstillerin geliştirilmesinde önemli etkenlerden biridir. Biyouyumluluk, bir biyomalzemenin vücut dokularına sağladığg optimum uyum olarak ifade edilmektedir. Bir malzemenin biyouyumlu olması için bulunduğu canlıdaki fizyolojik ortam tarafından kabul edilmesi gerekmektedir [87]. Kozmetik tekstil ürünlerinin kozmetik madde dăgıtım sistemi toksik ve kanserojen olmamalıdır. Vücut dışı uygulamalarda, kozmetik tekstiller aktif bileşenlerin salınması sırasında derinin tahriş olmasına neden olmamalıdır [88].

Kozmetik tekstil ürünleri incelenirken; ürün kullanımdan sonra talep edilen kozmetik etki, iddia edilen etkilerin klinik/kozmetik bağımsız kontrollü çalışmalarda gösterilmiş olması, ürünün etkisini görebilmek için gerekli uygulama süresi, yıkama dayanımları, çevre dostu olup olmadığı ve ürünün raf ömrü gibi olgular akla gelmektedir [89]. Bunlar 1şığında; kozmetik tekstillerin etkinliğinin, güvenirliğinin ve dayanıklılığının değerlendirilmesi ve test edilmesine ilişkin test standartlarının oluşturulması Avrupa Standardizasyon Komitesi tarafından sağlanmaktadır. Komite, 2004 yılında kozmetik özelliklere sahip tekstillerin etkinliği, toksisitesi, dayanıklılığı ve kimyasal analiz metotlarını incelemek üzere "Kozmetik tekstiller" grubunu kurmaya karar vermiş, 2006 yılında kozmetik tekstiller için teknik rapor geliştirmek için yeni bir çalışma grubu WG-25'i kurmuştur. Bu ön çalışmalardan sonra, 2009 yılında kozmetik tekstillerin test standartları yayımlanmıştır [90]. WG-25, standardizasyonun gerekli olduğu bazı önemli alanları belirlemiş ve kozmetik tekstillerin farklı yönleri üzerinde çalışmak üzere beş tane alt grup oluşturmuştur. Kozmetik tekstillerin hem öznel hem de nesnel değerlendirmeleri, çeşitli kozmetik etkilerin test edilmesi amacıyla kullanılmaktadır [3].

\section{A. KIMYASAL ÖZELLIKKLERIN BELİRLENMESI}

Kozmetik tekstil ürünlerinin asidik veya bazik karakteri, yanıcı olup olmaması veya başka bir maddeyle reaksiyona girme kapasitesi gibi kimyasal özellikleri mevcut yasal yönergelere ve kozmetik yasalarına göre test edilmektedir. Hali hazırda, hem tekstil hem de kozmetik ile ilgili olarak on üç yönetmelik tanımlanmakta ve listelenmektedir. Avrupa Kozmetik Yönetmeliği kozmetik ürünler için standartların geliştirilmesine yönelik çalışmalar yapmaktadır [3].

\section{B. ZEHIRLİ/ZARARSIZ OLMA}

Zehirlilik ve zararsızlık ile ilgili alt çalışma grubu, kozmetik tekstillerinin ilaç olarak kabul edilemeyeceği, yani sadece harici olarak kullanılabileceği sonucuna varmıştır. Kozmetiklerin ilk önce tekstil materyali üzerine uygulanması daha sonra ürünün cilde yakın olarak kullanılması gerekmektedir. Kozmetik tekstiller, EN ISO 10993, OECD test yöntemlerini başarılı bir şekilde geçmelidir (OECD 405, 406, 407 \& 471). OEKO TEX yöntemi de ayrıca başka bir seçenek olarak kullanılabilir. Kozmetik tekstiller piyasaya sürülmeden önce, kozmetik endüstrisindeki mevcut test standartlarına uygun olarak içerdiği etken maddenin test edilmesi ve nihai ürün olarak da biyolojik testlerden geçirilmesi gerekmektedir. Kullanılan test yöntemleri, maliyet ve güvenlik açısından bir dengede bulunmalıdır [3].

\section{E VITTAMINİ İÇERİĞi}

Tekstil yüzeylerindeki E vitamini içeriğinin testi, demir klorür çözeltisi ile E vitaminin indirgenme özelliklerini kullanarak renk reaksiyonu yoluyla kantitatif olarak gerçekleştirilebilmektedir. Nihai kozmetik tekstil ürünlerine $\mathrm{FeCl}_{3}{ }^{-}$çözeltisi damlatılır. E vitamini varlığında $\mathrm{Fe}_{3}{ }^{+}$iyonu $\mathrm{Fe}_{2}{ }^{+}$'ya indirgenir. Daha sonra $\mathrm{Fe}_{2}{ }^{+}$iyonlarının varlığında kırmızı şelat kompleksi oluşturan dipiridil çözeltisi damlatılmaktadır [3]. Ajala ve arkadaşları poliester kumaş yüzeyindeki E vitamini ve shea yağı varlığının karşılaştırılması ve kanıtı için FT-IR spektrumları ve termal gravimetrik analizler (TGA) yapmışlardır [91]. 


\section{ETKINLIKK}

Kozmetik tekstillerin etkinliğinin, kozmetik ürün standartları ile aynı koşullarda test edilmesi gerekmektedir. WG-25, bu sorunun karmaşıklığını çözmek için bazı kurallar koymayı kabul etmiştir. Kozmetik ürünler için hazırlanmasına rağmen, ISO / DIS 11930 testinin, kozmetik tekstillerin yararlılığını test etmede de başarılı olabileceği düşünülmektedir [92].

\section{E. PARFÜM PERFORMANS ANALIZI}

$\mathrm{Bu}$ analiz, çeşitli parfümlü tekstil ürünlerinin performansını test etmek için gereklidir. Gaz kromatografisi/kütle spektrometresi (GC/MS), uçucu bileşikleri analiz etmek için kullanılan özel bir yöntemdir. Hava sızdırmaz özellikli bir örnekleme kabına örnek yerleştirilmekte ve sonra belirli bir sıcaklığa kadar isıtılmaktadır. Isıtma sonucu oluşan parfümün etken maddeleri olan uçucu bileşenler, ASTM - D3362, D3452, D4128 gibi çeşitli ASTM standartlarına göre test edilmektedir [93].

\section{F. DAYANIKLILIK}

WG-25, kozmetik tekstillerin dayanıklılık özelliğini vurgulamak için ayrı bir alt grup oluşturmuştur. Y1kama haslığı için, bu alt grup tarafından birçok test yöntemi önerilmektedir. Bir tekstil yüzeyinde mikrokapsülleri bağlamak için kullanılan binder adı verilen yapıştırıcının etkinliği terbiye işleminde yer alan ürünlerin farklı arayüzlerinin uyumluluğuna bağlıdır. Genel olarak, mikrokapsüllerin bağlanması, tekstil yüzeylerinin kimyasal türüne ve yapısına bağlı olmaktadır [94].

\section{G. ETIKKETLEME}

WG-25 grubunun, kozmetik tekstillerin ambalajında etiketleme için bir standart koyma fizibilitesine ilişkin son toplantısında, kozmetik tekstillere dikilecek etiket ile ilgili ve ambalaj üzerine yazılacak açıklama ile ilgili olarak iki kısımdan oluşan öneride bulunulmuştur. WG-25 grubu hala kozmetik tekstiller için etiketleme standartlarını belirleme çalışmalarına devam etmektedir [3].

\section{SONUC}

Günümüzün bilinçli tüketicisi, birçok sektörde olduğu gibi tekstil sektörünü de konforlu ve multifonksiyonel özelliklerde ürünler tasarlamaya ve üretmeye teşvik etmektedir. Tekstil ürünleri, vücut içi aplikasyonlar ve hijyen ve bakım amaçlı olarak sağlık sektöründe halen yaygın olarak kullanılmaktadır. Kozmetik tekstiller, etken maddenin insan cildine daha uzun sürede ve daha konforlu bir şekilde aktarılmasına olanak sağlayabilen niş ürünlerin yer aldığı bir alan olarak karşımıza çıkmaktadır. Bu makalede, kozmetik tekstillerin tanımı ve tarihi giriş bölümünde verilmiş, üretim, sınıflandırılma ve karakterizasyon başlıkları altında daha detaylı bilgiler ve literatürde yer alan çalışmalar verilmiştir. Kozmetik tekstiller, kozmetik amaçlı etken maddeler içereceği gibi daha farklı cilt problemlerini hedeflemiş dermokozmetik etken maddeler hatta ciltten vücuda girmesi tercih edilen ilaçları içerebilir. Kozmetik tekstil mamulün tüketiciye sunulmadan önce, içereceği etken madde miktarının optimizasyonu ve kolayca oksitlenen isıya duyarlı bileşenlerin etkilerinin dayanıklılığının arttırılması araştırmacıları uğraştırıcı noktalardan olacaktır.

TEȘEKKÜR: Bu çalışma TÜBİTAK, tarafından desteklenmiştir (Proje no: 219M574).

\section{KAYNAKLAR}

[1] L. D. Almeida, "Functionalisation of textiles-future perspectives," presented at Congrès International de la Recherche Appliquée aux Textiles : (CIRAT2), Monastir, Tunisia, 2006. 
[2] H. K. Saini, and K. Manideep, "Cosmetotextiles: a novel technique of developing wearable skin care,” Asian Journal Of Home Science, vol. 12, no. 1, pp. 289-295, 2017.

[3] M. K. Singh, B. K. Behera, and V. K. Varun, "Cosmetotextiles: state of art," Fibers \& Textiles in Eastern Europe, vol. 19, no. 4 (87), pp. 27-33, 2011.

[4] H. Upadhayay, S. Jahan, and M. Upreti, "Cosmetotextiles: Emerging trend in technical textiles," Journal of Polymer and Textile Engineering, vol. 3, no. 6, pp. 8-14, 2016.

[5] K. Subramanian, N. Govindan, "Integration of cosmetics with textiles: An emerging area of functional textiles - a review," Journal of Textile Engineering \& Fashion Technology, vol. 4, no. 4, pp. 316-318, 2018.

[6] G. Doğan, "Elektrolif çekim yöntemiyle elde edilen biyopolimer nanoliflerin doku mühendisliği ve ilaç salımı uygulamalarında kullanım olanaklarının araştııılması," Doktora tezi, Fen Bilimleri Ensitüsü, Ege Üniversitesi, İzmir, Türkiye, ss. 184, 2012.

[7] D. Tiwari, N. Upmanyu, J. Malik, and S. Shivakant Shukla, "Cosmetotextiles used as a medicine," International Journal of Pharma and Chemical Research, vol. 3, no. 4, pp. 814-828, 2017.

[8] H. Shi, and J. H. Xin, "Cosmetic textiles: Concepts, application and prospects," Institute of Textiles \& Clothing, vol. 5, no. 9, pp. 21134-21138, 2007.

[9] L. Ripoll, C. Bordes, S. Etheve, A. Elaissari, and H. Fessi, "Cosmeto-textile from formulation to characterization: an overview," E-Polymers, vol. 10, no. 1, pp. 1-34, 2010.

[10] N. Agnihotri, R. Mishra, C. Goda, and M. Arora, "Microencapsulation - a novel approach in drug delivery: A review," Indo Global Journal Of Pharmaceutical Sciences, vol. 1, pp. 1-20, 2012.

[11] A. Madene, M. Jasquot, J. Scher, and S. Desobry, "Flavour encapsulation and controlled release - a review," International Journal of Food Science and Technology, vol. 41, pp. 1-21, 2006.

[12] K. Manjanna, B. Shivakumar, and T. Kumar Pramod, "Microencapsulation: An acclaimed novel drug delivery system for NSAIDs in arthritis," Critical Reviews ${ }^{\mathrm{TM}}$ in Therapeutic Drug Carrier Systems, vol. 27, no. 6, pp. 501-532, 2010.

[13] Ş. Eyüpoğlu ve D. Kut, "Mikrokapsülasyon teknolojisi ve tekstil sektöründe kullanımı," İstanbul Ticaret Üniversitesi Fen Bilimleri Dergisi, c. 15, s. 29, ss. 9-28, 2016.

[14] Y. Li, B. Tang, J. Chen, and P. Lai, "Microencapsulation of plum (Prunus salicina Lindl.) phenolics by spray drying technology and storage stability," Food Science and Technology, vol. 38, no. 3, pp. 530-536, 2018.

[15] G. Nelson, "Microencapsulation in textile finishing," Review of Progress in Coloration and related Topics, vol. 31, no. 1, pp. 57-64, 2001.

[16] R. Dubey, T. Shami, and K. Rao Bhasker, "Microencapsulation technology and applications," Defence Science Journal, vol. 59, no. 1, pp. 82-95, 2009.

[17] G. Erkan, "Bazı antifungal ajanların mikrokapsülasyonu ve tekstil materyallerine aplikasyonu," Doktora tezi, Fen Bilimleri Enstitüsü, Dokuz Eylül Üniversitesi, İzmir, Türkiye, ss. 146, 2008. 
[18] S. Karagönlü, "Medikal tekstil uygulamaları için antibakteriyel ajan içeren mikrokapsüllerin hazırlanması," Yüksek Lisans tezi, Fen Bilimleri Enstitüsü, Ege Üniversitesi, İzmir, Türkiye, ss. 84, 2011.

[19] S. Y. Cheng, M. W. Yuen, C. W. Kan, K. L. Cheuk, C. H. Chui, and K. H. Lam, "Cosmetic textiles with biological benefits: gelatin microcapsules containing vitamin C," International Journal of Molecular Medicine, vol. 24, pp. 411-419, 2009.

[20] V. Saez, J. R. Hernandez, and C. Peniche, "Microspheres as delivery systems for the controlled release of peptides and proteins," Biotecnología Aplicada, vol. 24, no. 2, pp. 108-116, 2007.

[21] H. K. Kaynak ve O. Babaarslan, "Mikroliflerin tekstil endüstrisindeki yeri ve önemi," Teknolojik Araştırmalar, c. 3, s. 3, ss. 70-83, 2009.

[22] S. Mukhopadhyay, and G. Ramakrishnan, "Microfibres," Textile Progress, vol. 40, no. 1, pp. 1$86,2008$.

[23] A. D. Gün, B. Demircan ve A. Şevkan, "Mikroliflerin üretim yöntemleri, özellikleri ve kullanım alanları," Tekstil ve Mühendis, c. 18, s. 83, ss. 38-46, 2011.

[24] I. S. S. Sharifah, A. A. B. Qairol, H. N. Azlina, and M. N. Khairusshima, "Thermal, structural and mechanical properties of melt drawn cur-loaded poly (lactic acid) fibers," Procedia Engineering, vol. 184, pp. 544-551, 2017.

[25] M. Rudilosso, "Modified Bombyx Mori silk fibers characterization," M.S. thesis, School of Industrial Engineering and Information, Politecnico di Milano, Milano, Italy, pp. 131, 2015.

[26] H.F. Şener ve F. Bulat, "Nanoteknoloji ile üretilen akıllı tekstiller ve tüketici beklentilerinin belirlenmesine yönelik bir araştırma," Hacettepe Üniversitesi Sosyolojik Araştırmalar E-Dergisi, ss. 1$14,2009$.

[27] J. Patra, and S. Gouda, "Application of nanotechnology in textile engineering:an overview," Journal Of Engineering And Technology, vol. 5, no. 5, pp. 104-111, 2013.

[28] Y. W. H. Wong, C. W. M. Yuen, M. Y. S. Leung, S. K. A. Ku, and H. L. I. Lam, "Selected applications of nanotechnology in textiles," AUTEX Research Journal, vol. 6, no. 1, pp. 1-8, 2006.

[29] F. Yilmaz, G. Celep, G. Tetik, "Nanofibers in cosmetics," in Nanofiber Research - Reaching New Heights, 1st ed., M. Rahman and A.M. Asiri, Eds. Croatia: Intechopen, 2016, pp. 127-146.

[30] P. Taepaiboon, U. Rungsardthong, and P. Supaphol, "Vitamin-loaded electrospun cellulose acetate nanofiber mats as transdermal and dermal therapeutic agents of vitamin A acid and vitamin E," European Journal of Pharmaceutics and Biopharmaceutics, vol. 67, no. 2, pp. 387-397, 2007.

[31] N. Charernsriwilaiwat, T. Rojanarata, T. Ngawhirunpat, M. Sukma, and P. Opanasopit, "Electrospun chitosan-based nanofiber mats loaded with Garcinia Mangostana extracts," International Journal Of Pharmaceutics, vol. 452, no. 1-2, pp. 333-343, 2013.

[32] İ. Gönülşen, "Portakal yağı içeren mikro ve moleküler kapsüllerin salım davranışlarının incelenmesi," Doktora tezi, Fen Bilimleri Enstitüsü, Dokuz Eylül Üniversitesi, İzmir, Türkiye, ss. 91, 2013.

[33] H. Issazadeh-Baltorki, and A. Khoddami, "Cyclodextrin-coated denim fabrics as novel carriers for ingredient deliveries to the skin," Carbohydrate Polymers, September vol. 110, pp. 513-517, 2014. 
[34] E. P. Akçakoca ve R. Atav, "Siklodekstrinlerin inklüzyon kompleksleri," Tekstil ve Konfeksiyon, c. 16, s. 2, ss. 94-99, 2006.

[35] F. D. Kadem ve Ş. Tölek, "Kaplamalı denim kumaşlarda performans özellikleri üzerine deneysel bir çalışma," Çukurova Üniversitesi Mühendislik-Mimarlık Fakültesi Dergisi, c. 31, s. 2, ss. 307-316, 2016.

[36] F. D. Kadem ve A. Ergen, "Farklı membranlı laminasyonlu kumaşların mukavemetlerinin araştırılması," Çukurova Üniversitesi Mühendislik-Mimarlık Fakültesi Dergisi, c. 26, s. 2, ss. 1-8, 2011.

[37] Y. Bulut, "Kaplamalı Giysilik Kumaşların Mekanik Özellikleri," Yüksek Lisans tezi, Fen Bilimleri Enstitüsü, Dokuz Eylül Üniversitesi, İzmir, Türkiye, ss. 99, 2010.

[38] T. Gencer, "Endüstriyel tekstillerde kullanılan poliüretan ve polivinilklorür esaslı kaplama yüzeylerin performans özelliklerinin incelenmesi," Yüksek lisans tezi, Fen Bilimleri Enstitüsü, Marmara Üniversitesi, İstanbul, Türkiye, ss. 80, 2015.

[39] E. H. Peker, "Akıllı giysilerin insan hayatındaki yeri," Tekstil El Kitabl, 2. bask1, İstanbul, Türkiye: TETSİAD Yayınları, 2013, böl. 4, ss. 125-126.

[40] B. Mahltig, H. Haufe, and H. Böttcher, "Functionalisation of textiles by inorganic sol-gel coatings," Journal Of Materials Chemistry, vol. 15, no. 41, pp. 4385-4398, 2005.

[41] M. T. Noman, M. A. Ashraf, and A. Ali, "Synthesis and applications of nano- $\mathrm{TiO}_{2}$ : A review," Environmental Science and Pollution Research, vol. 26, no. 4, pp. 3262-3291, 2019.

[42] Ü. Karahanlar, "Dokuma ve örme tekstiller üzerinde akıllı uygulamalar," Doktora tezi, Sosyal Bilimler Enstitüsü, Haliç Üniversitesi, İstanbul, Türkiye, ss. 223, 2014.

[43] G. Sayıt, "Mikrokapsül ve lipozom teknolojisi kullanarak kozmetik-tekstil üretimi," Doktora tezi, Fen Bilimleri Enstitüsü, Ege Üniversitesi, İzmir, Türkiye, ss. 140, 2005.

[44] F. Pricop, L. Chirilă, A. Popescu, M. Raşcov, and R. Scarlat, "Study regarding the development of the functional textiles with antimicrobial properties," presented at 7th Int. Conf. on Advanced Materials and Systems, 2018, Bucharest, Romania, 2018.

[45] G. Reinert, F. Fuso, R. Hilfiker, and E. Schmidt, "Uv-protecting properties of textile fabrics and their improvement," Textile Chemist \& Colorist, vol. 29, no. 12, pp. 36-43, 1997.

[46] D. Gupta, R. Chattopadhyay, and M. K. Bera, "Compression stockings structure property analysis," Asian Textile Journal, vol. 20, no. 1, pp. 39-45, 2011.

[47] M. I. Trenell, K. B. Rooney, C. M. Sue, and C. H. Thompson, "Compression garments and recovery from eccentric exercise: A (31) P-MRS study.," Journal of Sports Science and Medicine, vol. 5, no. 1, pp. 106-114, 2006.

[48] E. Y1lmaz ve Z. Öndoğan, "Fonksiyonel tekstillerde yükselen trend kozmetik tekstiller," XIII. Uluslararası İzmir Tekstil ve Hazır Giyim Sempozyumu, İzmir, Türkiye, 2014, ss. 146-150.

[49] B. Türsen ve Ü. Türsen, "Dermatolojide Aloe vera," Dermatoz, c. 5, s. 4, ss. 1-11, 2014.

[50] S. Cho, S. Lee, M. J. Lee, D. H. Lee, C. H. Won, S. M. Kim, and J. H. Chung, "Dietary Aloe vera supplementation improves facial wrinkles and elasticity and it increases the type 1 procollagen gene expression in human skin in vivo," Annals of dermatology, vol. 21, no. 1, pp. 6-11, 2009. 
[51] S. A. Ali, J. M. Galgut, and R. K. Choudhary, "On the novel action of melanolysis by a leaf extract of Aloe vera and its active ingredient aloin, potent skin depigmenting agents," Planta medica, vol. 78, no. 08, pp. 767-771, 2012.

[52] Z. Hajheydari, M. Saeedi, K. Morteza-Semnani, and A. Soltani, "Effect of Aloe vera topical gel combined with tretinoin in treatment of mild and moderate acne vulgaris: A randomized, double-blind, prospective trial," Journal Of Dermatological Treatment, vol. 25, no. 2, pp. 123-129, 2014.

[53] P. Puvabanditsin, and R. Vongtongsri, "Efficacy of Aloe vera cream in prevention and treatment of sunburn and suntan," Journal Of The Medical Association of Thailand, vol. 88, no. 4, pp. 173-176, 2005.

[54] M. K. Choo, E. K. Park, M. J. Han, and D. H. Kim, "Antiallergic activity of Ginseng and its Ginsenosides," Planta medica, vol. 69, no. 06, pp. 518-522, 2003.

[55] A. Taşdemir ve A. M. Yaman, "Ginsengin özellikleri ve sağlik üzerine etkileri," Sağllk Akademisi Kastamonu, c. 2, s. 3, ss. 211-222, 2017.

[56] S. Helms, "Cancer prevention and therapeutics: Panax ginseng," Alternative Medicine Review, vol. 9 , no. 3, pp. 259-274, 2004.

[57] D. O. Kennedy, A. B. Scholey, and K. A. Wesnes, "Modulation of cognition and mood following administration of single doses of Ginkgo biloba, Ginseng, and a Ginkgo/Ginseng combination to healthy young adults," Physiology \& Behavior, vol. 75, no. 5, pp. 739-751, 2002.

[58] C. Kan, C. Yuen, and L. Oya, "Aromatherapy in textiles," Textile Asia, vol. 36, no. 4, pp. 35$38,2005$.

[59] N. K. Nema, N. Maity, B. Sarkar, and P. K. Mukherjee, "Cucumis sativus fruit-potential antioxidant, anti-hyaluronidase, and anti-elastase agent," Archives of Dermatological Research, vol. 303, no. 4, pp. 247-252, 2011.

[60] P. Ziosi, S. Manfredini, S. Vertuani, V. Ruscetta, M. Radice, G. Sacchetti, and R. Bruni, "Evaluating essential oils in cosmetics: Antioxidant capacity and functionality," Cosmetics and Toiletries, vol. 125, no. 6, pp. 32-40, 2010.

[61] M. Dreger, and K. Wielgus, "Application of essential oils as natural cosmetic preservatives," Herba Polonica, vol. 59, no. 4, pp. 142-156, 2013.

[62] D. Kaczmarczyk, D. Strub, A. Polowy, W. I. L. K. Kazimiera, and S. Lochyński, "Selected essential oils in cosmetic emulsions: process oriented stability studies and antimicrobial activity," Natural Volatiles \& Essential Oils, vol. 2, no. 4, pp. 27-39, 2015.

[63] K. Murata, K. Takahashi, H. Nakamura, K. Itoh, and H. Matsuda, "Search for skin-whitening agent from prunus plants and the molecular targets in melanogenesis pathway of active compounds," Natural Product Communications, vol. 9, no. 2, pp. 185-188, 2014.

[64] M. Benita, Z. Dubinsky, and D. Iluz, "Padina pavonica: morphology and calcification functions and mechanism," American Journal of Plant Sciences, vol. 9, no. 06, pp. 1156, 2018.

[65] K. Sahayaraj, S. Rajesh, and J. M. Rathi, "Silver nanoparticles biosynthesis using marine alga Padina Pavonica (Linn.) and its microbcidal activity," Digest Journal of Nanomaterials \& Biostructures, vol. 7, no. 4, pp. 1557-1567, 2012. 
[66] N. Khaled, M. Hiba, and C. Asma, "Antioxidant and antifungal activities of Padina pavonica and Sargassum vulgare from the Lebanese Mediterranean Coast," Adv. Environ. Biol, vol. 6, no. 1, pp. 42-48, 2012.

[67] T. P. Stanojković, K. Scaron, G. Zdunić, Z. Kljajić, N. Grozdanić, and J. Antić, "In vitro antitumoral activities of Padina pavonia on human cervix and breast cancer cell lines," Journal Of Medicinal Plants Research, vol. 7, no. 8, pp. 419-424, 2013.

[68] K. Sakuma, M. Ogawa, K. Sugibayashi, K.I. Yamada, and K. Yamamoto, "Relationship between tyrosinase inhibitory action and oxidation-reduction potential of cosmetic whitening ingredients and phenol derivatives," Archives of Pharmacal Research, vol. 22, no. 4, pp. 335-339, 1999.

[69] Y. Higashi, and S. Tohda, "Simple HPLC analysis of hinokitiol in skin lotion with visible light detection after pre-column dabsylation," American Journal of Analytical Chemistry, vol. 8, no. 05, pp. $345,2017$.

[70] H. Yamano, T. Yamazaki, K. Sato, S. Shiga, T. Hagiwara, K. Ouchi, and T. Kishimoto, "In vitro inhibitory effects of hinokitiol on proliferation of Chlamydia trachomatis," Antimicrobial Agents and Chemotherapy, vol. 49, no. 6, pp. 2519-2521, 2005.

[71] M. Çayırlı ve G. Açıkgöz, "Vitamin E ve deri," Turkish Journal of Dermatology/Turk Dermatoloji Dergisis, c. 7, s. 2, ss. 87-90, 2013.

[72] M. Gianeti, and P. Maia, "Campos, efficacy evaluation of a multifunctional cosmetic formulation: The benefits of a combination of active antioxidant substances," Molecules, vol. 19, no. 11, pp. 18268-18282, 2014.

[73] S. H. Lim, and S. Hudson, "Review of Chitosan and its derivatives as antimicrobial agents and their uses as textile chemicals," Journal Of Macromolecular Science, Part Cpolymer Reviews, vol. 43, no. 2, pp. 223-269, 2003.

[74] F. E. Günes, "Medical use of squalene as a natural antioxidant," Clinical and Experimental Health Sciences, vol. 3, no. 4, pp. 221, 2013.

[75] V. Kostyuk, A. Potapovich, A. Stancato, C. De Luca, D. Lulli, S. Pastore, and L. Korkina, "Photo-oxidation products of skin surface squalene mediate metabolic and inflammatory responses to solar uv in human keratinocytes," Plos One, vol. 7, no. 8, pp. 1-11, 2012.

[76] Z. Yıldırım, N. Öncül ve M. Yıldırım, "Kitosan ve antimikrobiyal özellikleri," Niğde Üniversitesi Mühendislik Bilimleri Dergisi, c. 5, s. 1, ss. 19-36, 2016.

[77] R. C. Chien, M. T. Yen, and J. L. Mau, "Antimicrobial and antitumor activities of Chitosan from shiitake stipes, compared to commercial Chitosan from crab shells," Carbohydrate polymers, vol. 138, pp. 259-264, 2016.

[78] S. Rajput, and M. K. Singh, "Sericin - a unique biomaterial," Journal of Polymer and Textile Engineering, vol. 2, no. 3, pp. 29-35, 2015.

[79] J. A. Barajas-Gamboa, A. M. Serpa-Guerra, A. Restrepo-Osorio, and C. Ã lvarez-López, "Sericin applications: A globular silk protein," Ingeniería y competitividad, vol. 18, no. 2, pp. 193-206, 2016.

[80] T. Kitisin, P. Maneekan and N. Luplertlop, "In-vitro characterization of silk sericin as an antiaging agent," Journal Of Agricultural Science, vol. 5, no. 3, pp. 54, 2013. 
[81] A. Verbič, M. Gorjanc, and B. Simončič, "Zinc oxide for functional textile coatings: Recent advances," Coatings, vol. 9, no. 9, pp. 550, 2019.

[82] M. Z. Khan, V. Baheti, M. Ashraf, T. Hussain, A. Ali, A. Javid, and A. Rehman, "Development of UV protective, superhydrophobic and antibacterial textiles using $\mathrm{Zno}$ and $\mathrm{TiO}_{2}$ nanoparticles," Fibers And Polymers, vol. 19, no. 8, pp. 1647-1654, 2018.

[83] D. Manyasree, M. P. Kiran, and R. Ravikumar, "Cuo nanoparticles: Synthesis, characterization and their bactericidal efficacy," International Journal of Applied Pharmaceutics, vol. 9, no. 6, pp. 71$74,2017$.

[84] G. Borkow, "Using Copper to improve the well-being of the skin," Current chemical biology, vol. 8, no. 2, pp. 89-102, 2014.

[85] M. Ahamed, H. A. Alhadlaq, M. A. Khan, P. Karuppiah, and N. A. Al-Dhabi, "Synthesis, characterization, and antimicrobial activity of copper oxide nanoparticles," Journal of Nanomaterials, vol. 2014, 2014, Art. no. 637858, doi: 10.1155/2014/637858.

[86] Y. Özalp ve N. Özdemir, "Biyomateryaller ve biyouyumluluk," Ankara Üniversitesi Eczacllı Fakültesi Dergisi, c. 25, s. 2, ss. 57-72, 1996.

[87] C. Kan and C. Yuen, "Cosmetic textiles," Textile Asia, vol. 36, no. 6, pp. 29-35, 2005.

[88] G. Borkow, "Cosmetotextiles - sometimes the simple things work," Journal of Cosmetology \& Trichology, vol. 2, no. 1, pp. 1-2, 2016.

[89] H.-J. Buschmann, V. A. Dehabadi, C. Wiegand, "Medical, cosmetic and odour resistant finishes for textiles," in Functional Finishes for Textiles Improving Comfort, Performance and Protection, R. Paul, Eds. Cambridge, UK: Woodhead Publishing in association with The Textile Institute, 2015, pp. 316.

[90] E. O. Ajala, F. Aberuagba, A. M. Olaniyan, and K. R. Onifade, "Enzymatic extraction of shea butter: optimization study using response surface methodology," Journal of Food Process Engineering, vol. 40, no. 1, pp. e12329, 2015.

[91] V. Muñoz, J. S. Gonzalez, M. A. Martínez, and V. A. Alvarez, "Functional textiles for skin care active substance encapsulation," Journal of Textile Engineering \& Fashion Technology, vol. 2, no. 6, pp. 538-545, 2017.

[92] J. Zhu, and X. S. Chai, "Some recent developments in headspace gas chromatography," Current Analytical Chemistry, vol. 1, no. 1, pp. 79-83, 2005.

[93] F. Salaün, E. Devaux, S. Bourbigot, and P. Rumeau, "Application of contact angle measurement to the manufacture of textiles containing microcapsules," Textile Research Journal, vol. 79, no. 13, pp. 1202-1212, 2009. 